\title{
Radio-Chemotherapy as a Preoperative Treatment for Advanced Rectal Cancer. Evaluation of Down-Staging and Morbidity
}

\author{
M. Schaffer M. Thoma R. Wilkowski P. Schaffer E. Dühmke \\ Klinik und Poliklinik für Strahlentherapie und Radioonkologie der Universität München
}

Key Words

Rectal cancer · lonizing irradiation · Chemotherapy · Down-staging . Acute side effects

\section{Summary}

Background: The standard therapy for patients with clinically resectable rectal cancer is generally considered to be surgery. If the patient is diagnosed with advanced disease, postoperative radiochemotherapy (RCT) is usually recommended. In our study we aimed to investigate and analyze the effectiveness and toxicity of preoperative pelvic radiotherapy in combination with 5 -fluorouracil (5-FU) in locally advanced rectal cancer. Patients and Methods: From June 1999 to September 2001 we evaluated 50 consecutive patients [37 male and 13 female; average age 65.1 (range 46-79.5) years] with locally advanced rectal carcinoma. 32 patients were staged as uT3, 14 as uT4, and 4 as uT2. Regarding N-staging, 22 patients were diagnosed as uN0. 2 patients had distant metastases, with liver metastases in both instances. Conformal irradiation was performed with a box technique (4-field technique) with a dose of $45 \mathrm{~Gy}(5 \times 1.8 \mathrm{~Gy}$ per week for a total of 25 sessions). From days $1-5$ and $29-33$, all patients received $5-\mathrm{FU}\left(500 \mathrm{mg} / \mathrm{m}^{2}\right.$ per day, as a continuous i.v. injection). Results: Remission was observed in 28 patients $(56 \%)$, with down-staging of at least one T-stage. A better success rate was achieved for patients with deep-seated tumors $164 \%$ of the patients in this group). Complete remission was observed in 4 patients $(8.0 \%)$ and progression in $3(6.0 \%)$. 15 patients had no detectable change in tumor staging (30.0\%). A surgical R0 resection could be achieved in 43 patients, an $\mathrm{R} 1$ resection (minimal margin in 7. Side effects and toxicity (common toxicity criteria) of RCT included grade I-II dysuria in 5 patients $(10 \%)$, grade I-II diarrhea in 20 patients $(40 \%)$, and severe diarrhea in 2 patients $(4.0 \%)$. Grade I-II skin reaction was noticed in 22 patients $(44.0 \%)$, severe skin reaction only in 1 patient. Regarding acute postoperative morbidity, abscess and fistula formation was noted in 8 patients $(16.0 \%)$, with anastomosis leakage in 7 (14\%). Conclusion: Preoperative radiotherapy appears to be a feasible therapeutic approach with moderate toxicity and the potential to induce down-staging. The data presented in this study confirm the preliminary reports on this neoadjuvant treatment.
Schlüsselwörter

Rektumkarzinom · lonisierende Bestrahlung · Chemotherapie . Down-Staging · Akute Nebenwirkungen

\section{Zusammenfassung}

Hintergrund: Bei Patienten mit operablem Rektumkarzinom gilt als Standardbehandlung nach wie vor die chirurgische Resektion. Für Patienten in fortgeschrittenem Krankheitsstadium wird eine postoperative Radio-Chemotherapie (RCT) empfohlen. Ziel der vorliegenden Arbeit ist es, die Effektivität und Toxizität bei präoperativer Bestrahlung in Kombination mit 5-Fluorouracil (5-FU) bei lokal fortgeschrittenem Rektumkarzinom zu untersuchen. Patienten und Methoden: Im Zeitraum von Juni 1999 bis September 2001 wurden 50 Patienten (13 weiblich, 37 männlich) mit lokal fortgeschrittenem Rektumkarzinom untersucht. Der Altersdurchschnitt betrug 65,1 (Bereich 46-79,5) Jahre, 32 Patienten hatten einen uT3-Tumor, 14 Patienten einen uT4- und die restlichen 4 Patienten einem uT2Tumor. In Bezug auf den Lymphknotenstatus lag bei 22 Patienten ein N0-Stadium vor. 2 Patienten hatten Lebermetastasen. Die Strahlentherapie wurde konformal über eine 4-Felder-Box-Technik bis zu einer Gesamtdosis von 45,0 Gy (25 Fraktionen mit $5 \times 1,8$ Gy pro Woche) appliziert. An den Tagen 1-5 und 29-33 erhielten die Patienten 5-FU-Chemotherapie ( $500 \mathrm{mg} / \mathrm{m}^{2}$ pro Tag als Dauerinfusion). Ergebnisse: Bei $56 \%$ der Patienten $(n=28)$ wurde eine pathologische Remission um mindestens ein T-Stadium erreicht, mit besserem Erfolg bei tiefsitzenden Tumoren (64,0\% der Patienten in dieser Gruppe). Eine komplette Remission trat bei 4 Patienten $(8,0 \%)$ und ein Progress bei 3 Patienten $(6,0 \%)$ auf. Im Rahmen der Operation wurde bei 43 Patienten eine R0-Resektion erreicht, bei 7 Patienten eine R1-Resektion (mikroskopischer Tumorrest). Die Toxizität (common toxicity criteria) im Rahmen der RCT bestand aus Dysurie Grad I-II bei 5 Patienten $(10,0 \%)$, Diarrhoe Grad I-II bei 20 Patienten $(40.0 \%)$ und schwerer Diarrhoe nur bei 2 Patienten $(4,0 \%)$. Hautreaktionen Grad I-II traten bei 22 Patienten $(44,0 \%)$ auf, schwerere Hautreaktionen nur bei einem Patienten. Die akute postoperative Morbidität bestand aus Abszess- oder Fistelbildung bei 8 Patienten $(16,0 \%)$, Anastomoseninsuffizienz bei 7 Patienten $(14,0 \%)$. Schlussfolgerung: Als Ergebnis kann festgehalten werden, dass die präoperative RCT mit moderater Toxizität durchführbar ist und eine Tumorverkleinerung bewirken kann. Die Ergebnisse dieser Arbeit bestätigen die vorläufigen Daten anderer Arbeiten über das neoadjuvante Behandlungskonzept.

\begin{tabular}{ll}
\hline KARGER & ( ) 2002 S. Karger GmbH, Freiburg \\
Fax +497614520714 & Accessible online at: \\
$\begin{array}{l}\text { E-mail Information@Karger.de } \\
\text { www.karger.com }\end{array}$ & www.karger.com/journals/onk
\end{tabular}

Dr. Martin Thoma

Klinik und Poliklinik für Strahlentherapie und Radioonkologie der Universität München, Marchioninistr. 15

D-81377 München (Germany)

Tel. +49 89 7095-3770, Fax -6768

E-mail mschaffe@helios.med.uni-muenchen.de 


\section{Introduction}

Colorectal cancer is one of the leading cancer-related causes of death. In Germany, the incidence of colorectal carcinoma amounts to 55,000-60,000 cases per year, one third of which are rectal cancers. The mainstay of therapy has over the past 100 years been surgical resection. However, for the majority of rectal cancers treated conventionally by resection alone, locoregional recurrences are the major mode of failure [1]. Over the past decades, significant progress has been made in developing effective adjuvant regimens. During the last decade, substantial advances have been made with respect to treatment modalities and surgical management with a shift from radical operations to innovative sphincter-preserving techniques.

Postoperative combined-modality therapy has significantly contributed to improving local control and survival of patients. The local recurrence rate has been reduced dramatically with the use of radiotherapy, especially when combined with chemotherapy. Preoperative therapy (combined radio- and chemotherapy) has the potential advantages of producing less acute toxicity and increasing the possibility of sphincter preservation. Preoperative radiotherapy is becoming the standard of care for resectable, locally advanced adenocarcinoma of the rectum, being no longer limited to selected specialized cancer centers [2]. New and improved radiation techniques with conformal radiation and modern chemotherapeutic regimens may have the potential to further increase the therapeutic benefit.

Various reports on adjuvant treatment of advanced locoregional rectal carcinoma have been published, evaluating various radiation doses and chemotherapy regimens [3-11]. The irradiation regimen varies from 25 Gy fractionated in 5 sessions (hypofractionated radiotherapy) $[10,11]$ to conventional treatment between 36 and 50.4 Gy [3-9]. Some reports also combined preoperative with postoperative irradiation [7], others evaluated a combination treatment with hyperthermia [9]. All protocols included chemotherapeutic regimens, especially 5-fluorouracil (5-FU) and leucovorin. They differ, however, regarding the application modes and chemotherapy doses.

The pretreatment diagnosis is generally based on computed tomography (CT) [12], magnetic resonance imaging (MRI) [13, 14] or ultrasound (US) [15]. The effectiveness of MRI in comparison to CT has previously been demonstrated [14].

The objective of our current study is to evaluate down-staging and morbidity in the preoperative treatment of locoregionally advanced, rectal cancer with combined radio- and chemotherapy. In this nonrandomized retrospective study the morbidity and feasibility of this application method was analyzed. The study analysis was based on the ARO/AIO/ CAO trial [6].
Table 1. Patient characteristics

\begin{tabular}{ll}
\hline Age, years & \\
Median & 64.1 \\
Range & $46-79.5$ \\
Gender, f/m & $13 / 37$ \\
Stage & \\
Dukes B & 26 \\
Dukes C & 24 \\
Grading & \\
G1 & 2 \\
G2 & 42 \\
G3 & 6 \\
Tumor distance from anal verge \\
$\leq 5 \mathrm{~cm}$ & 25 \\
$>5 \mathrm{~cm}$ & 25 \\
\hline
\end{tabular}

\section{Material and Methods}

From June 1999 to September 2001 we evaluated 50 consecutive patients (37 male, 13 female) with an average age of 65.1 (range 46-79.5) years. All patients had been diagnosed with locally advanced rectal cancer. 32 patients suffered from a uT3 tumor, 14 patients had a uT4 and 4 patients a uT2 stage. Regarding N-staging, 24 patients were diagnosed as uN0 (table 1). Histological grading was rated G2 in 42 patients, G3 in 6 patients, and high-grade dysplasia in 2 patients. Staging was based on computed tomography (CT), magnetic resonance imaging (MRI) and endosonography [12-15]. Biopsies were taken during coloscopic control.

In 25 patients $(50.0 \%)$ the tumor was localized up to $5 \mathrm{~cm}$ from the anal verge (deep-seated tumor); in the remainder it was located more than $5 \mathrm{~cm}$ from the anal verge (high-seated tumor).

The patients were selected for preoperative irradiation based on staging results. The inclusion criteria were locally advanced rectal cancer with tumors that either penetrated the muscular layer of the bowel wall or the entire bowel wall (modified Dukes stages B) or spread to the lymph nodes in the same region (Dukes stages C).

Irradiation was applied using conformal irradiation with a box technique (4-field technique) up to a dose of $45 \mathrm{~Gy}(5 \times 1.8 \mathrm{~Gy}$ per week for a total number of 25 sessions). From days $1-5$ and days $29-33$, the patients received 5 -FU $\left(500 \mathrm{mg} / \mathrm{m}^{2}\right.$ per day, 24 -hour continuous infusion as is customary in our institution). 5-FU is a known radiosensitizer for rectal cancers. However, the dose to be applied varies among the different studies [3-6].

Based on published data [16], all patients underwent surgical intervention 6-8 weeks after radiochemotherapeutic treatment (RCT). 11 patients had an abdominoperineal rectal extirpation. The remaining 39 patients underwent deep anterior rectal resection with total mesorectal excision.

An updated clinical re-staging with CT or MRI was performed in 37 patients shortly after termination of therapy. The remaining 13 patients were operated in other hospitals and were not re-evaluated with CT and/or MRI. The following parameters were evaluated: (1) clinical remission after treatment, based upon CT and or MRI results [12-15]; (2) pathological remission after treatment based upon histological results after surgery; (3) complication rate caused by RCT; (4) postoperative morbidity. No evaluation of survival rate was done due to the short follow-up time. Morbidity and side effects were evaluated according to common toxicity criteria (CTC $[17,18])$.

\section{Results}

The clinical evaluation after RCT including CT and/or MRI findings demonstrated the following: In 15 patients no change 
Table 2. Clinical evaluation after RCT (based on CT or MR imaging). Subdivision between patients with tumor distance from anal verge $\leq 5 \mathrm{~cm}$ and those with tumor distance from anal verge $>5 \mathrm{~cm}$.

\begin{tabular}{|c|c|c|c|c|c|c|c|c|}
\hline & \multicolumn{2}{|c|}{$\begin{array}{l}\text { No } \\
\text { change }\end{array}$} & \multicolumn{2}{|c|}{$\begin{array}{l}\text { Partial } \\
\text { remission }\end{array}$} & \multicolumn{2}{|c|}{$\begin{array}{l}\text { Complete } \\
\text { remission }\end{array}$} & \multicolumn{2}{|c|}{ Progression } \\
\hline & $\mathrm{n}$ & $\%$ & $\mathrm{n}$ & $\%$ & $\mathrm{n}$ & $\%$ & $\mathrm{n}$ & $\%$ \\
\hline \multicolumn{9}{|c|}{ Tumor distance from anal verge } \\
\hline$\leq 5 \mathrm{~cm}$ & 6 & 30.0 & 10 & 50.0 & 2 & 10.0 & 2 & 10.0 \\
\hline$>5 \mathrm{~cm}$ & 9 & 52.9 & 7 & 41.2 & 1 & 5.9 & & \\
\hline Overall & 15 & 40.5 & 17 & 45.9 & 3 & 8.1 & 2 & 5.4 \\
\hline
\end{tabular}

\begin{tabular}{|c|c|c|c|c|c|c|c|c|}
\hline & \multicolumn{2}{|c|}{$\begin{array}{l}\text { No } \\
\text { change }\end{array}$} & \multicolumn{2}{|c|}{$\begin{array}{l}\text { Partial } \\
\text { remission }\end{array}$} & \multicolumn{2}{|c|}{$\begin{array}{l}\text { Complete } \\
\text { remission }\end{array}$} & \multicolumn{2}{|c|}{ Progression } \\
\hline & $\mathrm{n}$ & $\%$ & $\mathrm{n}$ & $\%$ & $\mathrm{n}$ & $\%$ & $\mathrm{n}$ & $\%$ \\
\hline Deep-seated tumor & 7 & 28.0 & 12 & 48.0 & 3 & 12.0 & 3 & 12.0 \\
\hline High-seated tumor & 8 & 32.0 & 16 & 64.0 & 1 & 4.0 & & \\
\hline Overall & 15 & 30.0 & 28 & 56.0 & 4 & 8.0 & 3 & 6.0 \\
\hline
\end{tabular}

\begin{tabular}{lrc}
\hline Partial remission in & $\mathrm{n}$ & $\%$ \\
\hline Tumor & 16 & 32.0 \\
Lymph nodes & 6 & 12.0 \\
Tumor and lymph nodes & 6 & 12.0 \\
Overall & 28 & 50.0 \\
\hline
\end{tabular}

Table 3a. Pathological evaluation after RCT and tumor resection in comparison with the clinical pretreatment status
Table 3b. Patients with pathologically confirmed partial remission, classified in tumor remission, lymph node remission, and remission in both
7 of these patients a leakage of the anastomosis site was noted $(14.0 \%)$. Other side effects were delayed wound healing (6.0\%), bleeding (3 patients), and cardiac complications ( 2 patients). Avulsion of the anal ampulla was seen in 1 patient, probably because of concrescence. Organ insufficiency was observed in 1 patient shortly after the surgical intervention.

\section{Discussion}

Although preoperative chemo-irradiation for locally advanced and high-risk rectal cancer improves the local recurrence rate [19-20], its adverse effects are not well defined. Differing reports on treatment regimens are the main problem [3-11]. Previous reports have demonstrated that neoadjuvant therapy is a well-tolerated treatment for adenocarcinoma of the rectum and that it may produce substantial down-staging and a highly curative resection rate. Nevertheless, the optimal timing of surgery after preoperative RCT in rectal cancer is unknown [16]. The study published by François et al. [16] proposed an interval between 6 and 8 weeks as opposed to a shorter interval of 2 weeks.

Chemo-irradiation has the potential to achieve a high response rate, even though the toxicity of this treatment can 
Table 4. Acute radiation-induced toxicities (following CTC scoring criteria)

\begin{tabular}{|c|c|c|c|c|c|c|c|c|}
\hline \multirow[t]{2}{*}{ Organ tissue } & \multicolumn{2}{|c|}{ Grade 1} & \multicolumn{2}{|c|}{ Grade 2} & \multicolumn{2}{|c|}{ Grade 3} & \multicolumn{2}{|c|}{ Grade 4} \\
\hline & $\mathrm{n}$ & $\%$ & $\mathrm{n}$ & $\%$ & $\mathrm{n}$ & $\%$ & $\mathrm{n}$ & $\%$ \\
\hline Skin & 12 & 24 & 10 & 20 & 1 & 2 & & \\
\hline Genitourinary & 4 & 8 & 1 & 2 & - & - & - & - \\
\hline $\begin{array}{l}\text { Lower gastrointestinal, } \\
\text { including pelvis }\end{array}$ & 12 & 24 & 8 & 16 & 2 & 4 & - & - \\
\hline
\end{tabular}

\begin{tabular}{llr}
\hline Complication & $\mathrm{n}$ & $\%$ \\
\hline Anastomosis leak & 7 & 14.0 \\
Abscess / fistula & 8 & 16.0 \\
Delay in wound healing & 3 & 6.0 \\
Bleeding & 3 & 6.0 \\
Cardiac complications & 2 & 4.0 \\
\hline
\end{tabular}

Table 5. Peri- and postoperative complications

sometimes be high. Some multicenter trials [5-7, 19-23] have aimed to evaluate the feasibility, morbidity and survival rate after preoperative RCT. A comparison of these trials is not easily done, since various treatment modalities, such as differing radiation doses (e.g. $5 \times 5$ Gy in the Dutch and Swedish trial, or 45-50.4 Gy in the CAO/ARO/AIO-94 trial) [6, 21, 22] and different administration routes of chemotherapy, were applied. Most of the studies published so far used 5-FU and leucovorin as both radiosensitizers and chemotherapy; however, the dosage applied and the administration routes differed. All trials were able to demonstrate the safety and feasibility of neoadjuvant RCT. Bosset et al. [23] could demonstrate a 5year disease-free survival in $92 \%$ of patients with T3M0 rectal cancer, when preoperative RCT was performed. The advantages of RCT as opposed to radiotherapy alone are already well known and accepted [3-11]. The most frequently used radiosensitizer is 5-FU. However, the dosage to be administrated and the duration of the application are still subject to dispute. The applied doses vary between 225 and $1,000 \mathrm{mg} / \mathrm{m}^{2}[6$, 23, 24]. Attempts to find other radiosensitizers [25] demonstrated Tagefur to have advantages over 5-FU in the treatment of rectal cancer. A recent report [26] suggested that the combination of oxaliplatin and irinotecan may have the potential to further increase the therapeutic benefit of rectal cancer. The basic issue of timing (pre- or postoperative) within a multimodal regimen is currently under investigation. However, several reports were not able to demonstrate significant down-staging after preoperative treatment [11]; it needs to be taken into consideration, though, that the treatment regimens reported in these studies included irradiation regimens of $5 \times 5$ Gy and surgical intervention within 10 days after RCT. In comparison, other reported treatment regimens applied 40-50.4 Gy and performed surgery 4-6 weeks after preoperative treatment [3-10]. With modern radiation techniques, preoperative radiotherapy can be delivered without any substantial increase in postoperative mortality or morbidity and with a low rate of late toxicity, provided that the radiation technique is optimal.

Our results correlated well with the above-mentioned literature in that they achieved clinical and pathological down-staging in 45.9 and $56.0 \%$ of cases, respectively. The complete remission rate was low $(8.1 \%$ clinical and $8.0 \%$ pathological $)$ as is to be expected for locally advanced tumor. The correlation between clinical and pathological staging is also confirmed and corresponds to the already known literature [12-15].

The most common form of acute toxicity encountered during adjuvant pelvic irradiation is diarrhea (approximately $24 \%$ of the patients). Skin reaction (perineal dermatitis) is also known (approximately 30-40\%) [27]. The postoperative morbidity, such as anastomotic leak (14.0\%) and abscess formation $(16.0 \%)$, was higher as compared to reports on postoperative irradiation regimens [6]. Bleeding and delay of wound healing were the same in our preoperative group in comparison to postoperative irradiation reports [6].

Our nonrandomized retrospective study analyzed the morbidity and feasibility of this application method. A long-term survival rate evaluation was not possible as yet, since follow-up times were still short, with a mean of 7.6 (range 3-26) months. In conclusion, preoperative radiotherapy is a feasible method with moderate toxicity and a potential to induce down-staging. Our data confirm the preliminary reports about this neoadjuvant treatment. 


\section{References}

$1 \mathrm{Hu}$ KS, Harrison LB: Adjuvant therapy for resectable rectal adenocarcinoma. Semin Surg Oncol 2000; 19:336-349.

2 Ngan SY: Optimising treatment for resectable rectal cancer: Is preoperative therapy beneficial? Drugs Aging 2001;18:79-85.

3 Janian NA, Crane C, Feig BW, Cleary K, Dubrow R, Curely S, Vauthey JN, Lynch P, Ellis LM, Wolf R, Lenzi R, Abruzzese J, Pazdur R, Hoff PM, Allen $\mathrm{P}$, Brown T, Skibber J: Improved overall survival among responders to preoperative chemo-radiation for locally advanced rectal cancer. Am J Clin Oncol 2001;24:107-112.

4 Grann A, Fang C, Wong D, Saltz L, Paty PP, Guillem JG, Choen AM, Minski BD: Preoperative combined modality therapy for clinically resectable uT3 rectal adenocarcinoma. Int J Radiat Oncol Biol Phys 2001;49:987-995.

5 Tjandra JJ, Reading DM, McLachlan SA, Gunn IF, Green MD, McLaughin SJ, Millar JL, Pedersen JS Phase II clinical trial of preoperative combined chemoradiation for $\mathrm{T} 3$ and $\mathrm{T} 4$ resectable recta cancer: Preliminary results. Diss Colon Rectum 2001;44:1113-1122.

6 Sauer R, Fietkau R, Wittekind C, Martus P, Rode C, Hohenberger W Jatzko G, Stabitzer H, Karstens JH, Becker H, Hess C, Raab R: Adjuvant versus neoadjuvant radiochemotherapy for locally advanced rectal cancer. A progress report of a phase-III randomized trial (Protocol CAO/ARO/AIO-94). Strahlenther Onkol 2001;177:173-181.

7 Chan AK, Wong AO, Langevin J, Jenken D, Heine J, Buie D, Johnson DR: Preoperative chemotherapy and pelvic radiation for tethered or fixed rectal cancer: A phase II dose escalation study. Int J Radiat Oncol Biol Phys 2000; 48:843-856.

8 Read TE, McNevin MS, Gross EK, Whiteford HM, Lewis JL, Ratkin G, Picus J, Birnbaum EH, Flesh man JW, Kodner IJ, Myerson RJ: Neoadjuvant therapy for adenocarcinoma of the rectum: Tumor response and acute toxicity. Dis Colon Rectum 2001;44:513-522.

9 Rau B, Wust P, Riess H, Schlag PM: Radiochemotherapy plus hyperthermia in rectal carcinoma. Schweiz Rundsch Med Prax 2001;90:587-592.
10 Lammering G, Hartmann KA, Frenken M, Aryus B, Doker R, Ulrich B: Short-term hypofractionated radiotherapy followed by total mesorectal excision. Strahlenther Onkol 2000;176:555-559.

11 Marijnen CA, Nagtegaal ID, Klein Kranenberg E, Hermans J, van der Velde CJ, Leer JW, Van Krieken JH: No downstaging after short term preoperative radiotherapy in rectal cancer patients. J Clin Oncol 2001;19:1976-1984.

12 Chiusura-Corona M, Muzzio PC, Giust G, Zuliani M, Pucciarelli S, Toppan P: Rectal cancer: CT local staging with histopathological correlation. Abdomen Imaging 2001; 26:134-138.

13 Wallenggren NO, Holtas S, Andren Sandberg A, Jonsson E, Kristofferson DT, McGill S: Rectal carcinoma: Double-contrast MR imaging for preoperative staging. Radiology 2000;215:108-114.

14 Marone P, Petrulio F, de Bellis M, Battista Rossi G, Tempesta A: Role of endoscopic ultrasonography in the staging of rectal cancer: A retrospective study of 63 patients. J Clin Gastroenterol 2000;30: 420-424.

15 Beets-Tan RG, Beets GL, Borstlap AC, Oei TK, Teune TM, von Meyenfeldt MF, van Engelshoven JM: Preoperative assessment of local tumor extent in advanced rectal cancer: CT or high-resolution MRI? Abdomen Imaging 2000;25:533-541.

16 François Y, Nemoz CJ, Baulieux J, Vignal J, Grandjean JP, Partensky C, Souquet JC, Adeleine P, Gerard JP: Influence of the interval between preoperative radiation therapy and surgery on downstaging and on the rate of sphincter-sparing surgery for rectal cancer: The Lyon R90-01 randomized trial. J Clin Oncol 1999:17:2396.

17 Seegenschmiedt MH: Interdisciplinary documentation of treatment side effects in oncology. Presen status and perspectives. Strahlenther Oncol 1998; 174(suppl 3):25-29.

18 Trotti A: The evolution and application of toxicity criteria. Semin Radiat Oncol 2002;12(suppl 1):1-3.

19 Kapiteijn E, Marijnen CA, Nagtegaal ID, Putter H, Steup WH, Wiggers T, Rutten HJ, Pahlman L, Glimelius B, van Krieken JH, Leer JW, van de Velde CJ: Preoperative radiotherapy combined with total mesorectal excision for resectable rectal cancer. N Engl J Med 2001;345:690-692.
20 Martling A, Holm T, Johansson H, Rutqvist LE, Cedermark B: The Stockholm II trial on preoperative radiotherapy in rectal carcinoma: Long term follow-up of a population-based study. Cancer 2001;92:896-902.

21 Marijnen CA, Kapiteijn E, van de Valde CJ, Martijn H, Steup WH, Wiggers T, Kranenbarg EK, Leer JW; Cooperative Investigators of the Dutch Colorectal Cancer Group. Acute side effects and complications after short term preoperative radiotherapy combined with total mesorectal excision in primary rectal cancer: Report of a multicenter randomized trial. J Clin Oncol 2002; 20:817-825.

22 Dahlberg M, Glimelius B, Pahlman L: Improved survival and reduction in local failure rates after preoperative radiotherapy: Evidence for the generalisability of the results of Swedish rectal cancer trial. Ann Surg 1999;229:493-497.

23 Bosset JF, Magnin V, Maingon P, Mantion G Pelissier EP, Mercier M, Chaillard G, Horiot JC Preoperative radiochemotherapy in rectal cancer: Long term results of a phase II trial. Int J Radiat Oncol Biol Phys 2000;46:323-327.

24 Mehta VK, Poen J, Ford J, Edelstein PS, Viera M, Bastidas AJ, Young H, Fisher G: Radiotherapy, concomitant protracted-venous-infusion 5-flurouracil, and surgery for ultrasound-staged $\mathrm{T} 3$ or T4 rectal cancer. Dis Colon Rectum 2001;44:52-58

25 Calvo FA, Gomez-Espi M, Diaz-Gonzalez JA, Cantalapiedra R, Marcos P, Alvarado A, Garcia Alfonso P, Herranz R, Alvarez E: Pathologic downstaging of T3-4Nx rectal cancer after chemoradiation: 5-fluorouracil vs. Tegafur. Int J Radiat Oncol Biol Phys 2001;51:1264-1270.

26 Rodel C, Sauer R: Perioperative radiotherapy and concurrent radiochemotherapy in rectal cancer. Semin Surg Oncol 2001;20:3-12

27 Martenson JA, Gunderson LL: Colon and Rectum in Perez CA, Brady LW (eds): Principles and Practice of Radiation Oncology, ed 3. Philadelphia, Lippincott-Raven, 1977, pp 1489-1510. 